\title{
POCZATKUJACY NAUCZYCIEL PRZEDSZKOLA WE WSPÓLNOCIE ZAWODOWEJ. OD NIEPEWNOŚCI KU PEŁNEMU UCZESTNICTWU W SOCJOKULTUROWYCH PRAKTYKACH
}

\begin{abstract}
Streszczenie: Celem artykułu jest przedstawienie społecznego wymiaru uczenia się profesji przez początkującego nauczyciela przedszkola, wagi, jaką w tym procesie może zajmować uczestniczenie w socjokulturowych praktykach wspólnoty. Autorka rozwija tezę, iż jedynie partycypacja nowicjusza w działaniach wspólnoty nauczycieli prowadzi do stopniowego stawania się nauczycielem. W pierwszej kolejności omówione jest podstawowe dla rozważań pojęcie wspólnoty postrzeganej w optyce kulturowej, ze zwróceniem uwagi na dwa wymiary: współpracę i zaufanie. Następnie podjęty jest wątek zaangażowania się nowicjusza w sprawy wspólnoty, odnajdywania w niej swojego miejsca. Na zakończenie omówiona została rola tworzenia sieci wsparcia umożliwiającej nowicjuszowi partycypację w dyskursie na temat podejmowanych aktywności.
\end{abstract}

Słowa kluczowe: początkujący nauczyciel; wspólnota nauczycieli; socjalizacja nauczycieli; kultura przedszkola; edukacja przedszkolna.

\section{Wprowadzenie}

Wejście do społeczności zawodowej, będącej wzorem minispołeczeństwa - używając określenia Garetha Morgana (2005, s. 136) - pociąga za sobą pewien zestaw zobowiązań wobec siebie i wspólnoty. Sytuacja startu zawodowego oznacza dla nowicjusza nie tylko podjęcie nowych obowiązków, lecz także uczenie się, osadzanie się w roli związane m.in. z podążaniem za akceptowanymi wzorami zachowań, przekonaniami, wartościami, które zostały uformowane lub obecnie są uznawane przez członków społeczności (Kurantowicz 2007, s. 43). Motywem uczenia się nowego członka grupy staje się wtedy konieczność adaptacji do panujących w danej

2 Dr Magdalena Grochowalska, Uniwersytet Pedagogiczny im. KEN w Krakowie, Instytut Pedagogiki Przedszkolnej i Szkolnej; e-mail: magdalena.grochowalska@up.krakow.pl. 
wspólnocie wzorców działania, uznania, przyjętych w niej reguł społecznych oraz potrzeba podejmowania nowych aktywności, zmagania się z sytuacjami, w których rozwiązanie nie jest znane (Madalińska-Michalak 2016, s. 60). Kompetencje rozwinięte podczas przygotowania do zawodu nie zawsze przystają do osadzonej w kontekście praktyki pedagogicznej. Początkujący nauczyciel może doświadczyć sytuacji, oczekiwań ze strony innych, dla sprostania którym nie posiada wystarczających kompetencji, te rozwijają się bowiem w toku całożyciowego uczenia się, także w miejscu pracy (Czubak-Koch 2014; Grochowalska 2015). Dla rozwijania poczucia kompetencyjności na etapie startu zawodowego za czynniki niezbędne uważane są przede wszystkim doświadczenie wsparcia, aktywne włączanie się nowicjusza w życie społeczności zawodowej, zaangażowanie w poznawanie kultury grupy oraz możliwość uczenia się w interakcjach, nawiązywania relacji (Howes i in. 2003).

Przywołana w tytule kategoria „praktyka socjokulturowa” odnosi się do rozumienia praktyki jako dyskursu konstruowanego przez podmioty na temat swej aktywności. W tym znaczeniu praktyka to działanie komunikacyjne wpisane $\mathrm{w}$ relacje między podmiotami. Zakłada ona wzajemność oddziaływań podmiotów zaangażowanych w konstruowanie sensu działań oraz sposobów organizacji aktywności (Barbier 2016, s. 171). Tak ujmowany dyskurs stanowi przestrzeń komunikacyjną, w której uczestnicy podzielają wspólną perspektywę oglądu rzeczywistości, tworzą świat społeczny (Kacperczyk 2012, s. 276). Podzielany przez wiele podmiotów sposób, w jaki dochodzi do konstrukcji sensu podejmowanej aktywności, buduje kulturę działania, a w odniesieniu do nauczycieli - działania profesjonalnego. Konstruowanie sensu zachodzi wyłącznie w oparciu o te aktywności, w które podmioty są zaangażowane (Barbier 2016, s. 114-116). Oznacza to, że nabywanie sensu przez aktywność, w której się uczestniczy, jest procesem długotrwałym, ewoluującym, a od początkującego nauczyciela wymagającym bezpośredniego zaangażowania w praktyki wspólnoty. Celem wskazanego w tytule przejścia (od niepewności do uczestnictwa w praktykach) jest zasygnalizowanie procesu transformacji $\mathrm{w}$ aktywności nowicjusza związanego $\mathrm{z}$ procesem uczenia się w wymiarze indywidualnym i społecznym.

W odniesieniu do nauczycieli przedszkola proces społecznego uczenia się, rozwijanie kompetencji zawodowych mogą mieć szczególny charakter, związany z powszechnym wśród społeczeństwa sposobem spostrzegania pierwszego etapu edukacji. Niejednokrotnie obraz przedszkola, także kreowany przez media, jest przedstawiany przede wszystkim jako miejsce zabawy i opieki nad dzieckiem. Celem podjętych rozważań jest przedstawienie jednej z perspektyw oglądu funkcjonowania zawodowego nauczyciela przedszkola, a mianowicie wagi, jaką w tym procesie może zajmować uczestniczenie w socjokulturowych praktykach wspólnoty nauczycieli. Przyjmując, że kontekstem dla pracy zawodowej jest przestrzeń związana $\mathrm{z}$ uczestnictwem $\mathrm{w}$ działaniach wspólnotowych, które początkujący nauczyciel poznaje i współtworzy, artykuł jest rozwinięciem tezy, iż jedynie partycypacja nowicjusza w działaniach wspólnoty nauczycieli prowadzi do stopniowego 
stawania się nauczycielem. Proces stawania się nauczycielem postrzegany jest $\mathrm{w}$ tym miejscu w odniesieniu do społecznego wymiaru uczenia się profesji, relacji z innymi podmiotami, w których jednostka się staje, działań podejmowanych na rzecz innych. Ze względu na szeroki zakres zagadnienia podjęta refleksja przedstawia niewielki zakres zjawiska i jest częścią szerszych badań dotyczących stawania się nauczycielem małego dziecka.

\section{Wspólnota nauczycieli w optyce kulturowej}

Wspólnotowość, obok sprawczości, uznawana jest w psychologii społecznej za podstawowy wymiar spostrzegania ludzi i samego siebie. Związana jest z dążeniem do budowania więzi, przynależności do grup społecznych (np. zawodowych), tworzeniem i utrzymywaniem relacji społecznych. Poczuciu przynależności sprzyja angażowanie się jednostki w aktywność społeczną, a odrzucenie czy brak akceptacji ze strony grupy powoduje jego utratę. Warto podkreślić, że to nie zabezpieczenie potrzeb uznania i przynależności staje się jedną z głównych przyczyn (obok przesłanek związanych z polityką edukacyjną) odchodzenia początkujących nauczycieli z zawodu (Kelchtermans 2017). Psychologowie, ujmując wspólnotowość jako koncentrację na celach innych ludzi i własnych $\mathrm{z}$ nimi relacjach, podkreślają, że jest ona zasobem dobroczynnym zarówno dla jej posiadacza, jak i dla innych (Wojciszke, Cieślak 2014, s. 292-293). Początkującemu nauczycielowi może ona pomóc w przezwyciężeniu poczucia niepewności, towarzyszącego wrastaniu we wspólnotę nauczycieli. Magdalena Środa (2003, s. 257) podkreśla, iż wspólnota nie jest zbiorowiskiem swobodnie działających osób, lecz jest kolektywem, który ma własną tożsamość, cele, to grupa ludzi, między którymi istnieją afektywne relacje, wspólne wartości, normy, znaczenia, historie, z którymi się identyfikują. Dla nowicjusza ich poznanie jest trudnym zadaniem. Stając się częścią świata społecznego, dzielonego z innymi, równocześnie inaczej doświadcza on, interpretuje i działa.

Świat społeczny nauczycieli tworzących wspólnotę trafnie opisuje metafora orkiestry. Jest to przykład pracy zespołowej, w której każdy stara się grać perfekcyjnie, lecz sukces zależy od wzajemnego wsłuchiwania się muzyków w siebie, wspólnego uczenia się i dostrajania w dążeniu do realizacji podzielanego przez wszystkich celu. Może ona powstać o tyle, o ile tworzą ją ludzie zaangażowani we wspólne doświadczenia, wspólne rozwiązywanie problemów, przy czym angażując się we wspólne przedsięwzięcia, realizują osobiste i grupowe cele. Spotykają się, aby się podzielić wiedzą, dopiero bowiem jako zespół posiadają wiedzę potrzebną do wspólnego namysłu. Społeczności te powstają samoistnie, w sposób nieformalny, a rozwijają się wokół spraw znaczących dla danej grupy. Co ważne, wspólnotę praktyków tworzą ludzie, którzy posiadają różne doświadczenia - zarówno nowicjusze, jak i nauczyciele kończący karierę - oraz różne zasoby wiedzy profesjonalnej, są jednak przekonani o potrzebie wzajemnego uczenia się od siebie (Kędzierska, Maciejewska 2014). W sytuacjach trudnych, transgresyjnych - a taką jest niewątpliwe rozpoczęcie 
pracy zawodowej - szczególnie ważne stają się codzienne, nieformalne relacje z innymi nauczycielami, które mogą sprzyjać zaangażowaniu się w życie wspólnoty.

Z powyższym opisem koresponduje teza Ewy Kurantowicz (2007), odnosząca się do obecności innych w społecznym uczeniu się jednostki. Autorka twierdzi, iż występujące powszechnie osłabienie tradycyjnych więzi i relacji we wspólnotach czy grupach edukacyjnych jest wzmacniane kulturowo przez procesy indywidualizacji życia społecznego. Oznacza to, że jednostka, poprzez „uwolnienie się” z kontrolujących ją norm społecznych z jednej strony ogranicza wpływ wspólnoty, z której pochodzi, zaś z drugiej może wybierać wspólnoty, do których chce należeć. Początkujący nauczyciel, dążąc do uczestnictwa w działaniach wspólnotowych, nie tylko odtwarza hipotezy, które społecznie już funkcjonują, lecz także podejmuje się refleksyjnego i krytycznego konstruowania własnych hipotez i teorii (Muchacka, Czaja-Chudyba 2018). Jest to długotrwały proces uczenia się, wymykający się normalizacji i standaryzacji, dla którego można przedstawić jednorodny plan działania. Będąc rezultatem interakcji między nauczycielem a kontekstem zawodowym, w którym nauczyciel pracuje, jest równocześnie połączony ze zmianą osobowościową. Badania prowadzone na etapie startu zawodowego pokazują, że dla uczenia się w grupie zawodowej istotne są doświadczenia gromadzone podczas uczestniczenia w sieci interakcji. Nowicjusze, biorąc udział w różnorodnych programach wprowadzających, mogą podzielić się swoimi osiągnięciami, podjąć refleksję nad odczuwanymi dylematami. Refleksja zaś pozwala nowym nauczycielom skupić się na procesie uczenia się we wspólnocie. Współpraca z innymi nauczycielami oraz mentorami, przebiegająca w społeczności autentycznego dialogu i wzajemnego szacunku, pozwala nowicjuszowi w nowy dla siebie sposób interpretować praktykę pedagogiczną. Wzmacnianiu refleksji nad własnym działaniem służy uczenie się w kulturze krytycznego dialogu, którego zaistnienie wymaga proaktywnego zaangażowania się w sieć interakcji interpersonalnych i międzyorganizacyjnych, co pozwala koncentrować się na procesach uczenia się od innych (Cherubini 2009). Zaangażowanie się w społeczność zawodową uważane jest za podstawę indywidualnie podejmowanej krytycznej refleksji nad koncepcją edukacji, krytycznego myślenia i zadawania pytań (Curry i in. 2008, s. 660).

Nieco odmienną perspektywę analizy uczenia się przez zaangażowanie w działania wspólnoty wskazuje Joanna Madalińska-Michalak (2016). Cytowana autorka zwraca uwagę na granice uczenia się nauczycieli, związane z warunkami pracy, relacjami władzy, osobami pracującymi oraz konfliktami występującymi w środowisku pracy. Analizując problematykę usytuowania wspólnoty praktyków w szkole 1 , w miejscu indywidualnego i zespołowego uczenia się, rozpoznać można ograniczenia, jakie niesie ze sobą przynależenie do tego typu wspólnoty. W odniesieniu do koncepcji sytuacyjnego uczenia się, Etienne Wenger dowodzi,

1 Rozważania dotyczą uczenia się w szkolnej wspólnocie. W równym stopniu można je - w moim przekonaniu - odnieść do wspólnoty praktyków w przedszkolu. 
że to natura organizacji i przyjęte w niej cele determinują uczenie się nauczycieli. „[O]d nauczyciela jako członka wspólnoty praktyków wymaga się z jednej strony umiejętności adaptacji do panujących w danej wspólnocie wzorców działania, z drugiej zaś twórczej aktywności, umiejętności zmagania się z sytuacjami nowymi i podejmowania działań, dla których brakuje gotowych rozwiązań" (Madalińska-Michalak 2016, s. 60), co niewątpliwie stanowi dla nowicjusza wyzwanie.

Można zatem zwrócić uwagę, iż kontekstem społecznego uczenia się staje się kultura organizacyjna przedszkola, która w sposób niezwykły łączy ludzi wykonujących razem określone prace. Powoduje ona, że nauczyciele zaczynają stanowić pewną wspólnotę, niepojętą dla ludzi z zewnątrz. Kultura jest „czymś, w czym ogniskuje się cała magia tego, co społeczne, [...] co zagadkowe i złożone, a jednocześnie konstytutywne dla środowiska pracy" (Kołodziej-Durnaś 2012, s. 447). Przedszkole jako organizacja widziana w metaforze kulturowej (Morgan 2005, s. 125-160) stwarza możliwość poznania procesu budowania rzeczywistości, takiego, który pozwala ludziom dostrzegać i w charakterystyczny sposób rozumieć szczególne wydarzenia, działania, przedmioty czy wypowiedzi, jest również podstawą do nadawania sensu własnemu zachowaniu. Odczytywanie przedszkola jako zjawiska kulturowego pozwala rozpoznać funkcjonujące w nim normy kulturowe, które nie pozostają bez znaczenia dla uczenia się nowicjusza, uwarunkowanego preferencjami oraz stylem funkcjonowania grupy.

W przedszkolu, jak w każdej organizacji, mogą współistnieć odmienne wymiary tej samej kultury, czego konsekwencją jest tzw. kultura rozczłonkowana (Morgan 2005, s. 138). Pierwsza, jawna - kultura publiczna, którą łatwo opisać powierzchownie, jest na użytek wspólny. Mimo że ludzie ją tworzący mogą charakteryzować się zaangażowaniem, harmonijnym funkcjonowaniem, być odpowiedzialni, w prywatnym otoczeniu mogą wyrażać zdziwienie lub czasami nawet oburzenie wobec sposobu postępowania innych. Druga kultura, o wiele trudniejsza do zidentyfikowania, jest kulturą ukrytą, głęboką, a jej poznanie staje się możliwe jedynie przez aktywne uczestnictwo w życiu wspólnoty. Dla kultury rozczłonkowanej - a w niej rozczłonkowanych grup (Morgan 2005, s. 152) - charakterystyczne jest istnienie wielości rzeczywistości. W ślad za tezą, iż „kultura nie jest harmonijnie uzgodnioną zasadą, ale „pofragmentaryzowaną" jednością, a członkowie organizacji są jednocześnie osobni i zjednoczeni” (Kołodziej-Durnaś 2012, s. 171) można przypuszczać, że zachowanie jedności w działaniach wspólnoty w perspektywie różnorodności jej członków jest zadaniem trudnym. Mimo że wszyscy nauczyciele uczestniczą w praktykach socjokulturowych tego samego przedszkola, to mogą mieć różny ogląd tego, czym winna być praktyka pedagogiczna realizowana w tym miejscu.

Spojrzenie na aktywność początkującego nauczyciela przez pryzmat socjokulturowych praktyk kieruje naszą uwagę na wymiary szczególnie znaczące dla funkcjonowania wspólnot nauczycielskich. 


\section{Współpraca i zaufanie jako determinanty wspólnoty}

Dla sposobu, w jaki ludzie kształtują relacje społeczne, dla zaistnienia wspólnoty, istotne znaczenie mają zmiany zachodzące we współczesnych organizacjach. W świecie pracy socjolog Richard Sennett (2013), identyfikując osłabienie współpracy, zauważa, że jej jakość istotnie zależy od relacji społecznych i poczucia zaufania. Wartość oraz granice bezpośrednich relacji stają się dla człowieka możliwe do poznania przez proces wchodzenia w świat (można dodać także zawodowy), który jest dla Sennetta (2013, s. 354) wspólnotą. Rozważając warunki funkcjonowania wspólnot, cytowany autor podkreśla, iż to relacje nieformalne zachodzące w organizacji wyznaczają siłę współpracy i zaufania (Sennett 2013, s. 211). Zaufanie, niezwiązane z zajmowanym stanowiskiem czy relacją nadrzędności-podrzędności, pełni istotną rolę w podtrzymywaniu relacji.

Cytowany powyżej autor zwraca uwagę na dwa oblicza współpracy. Z jednej strony, praca razem, w relacji - to wymiana korzystna dla wszystkich zaangażowanych w nią osób, której istotą jest aktywne uczestnictwo, a nie bierna obecność. $Z$ drugiej, to także wyzwanie, ponieważ dotyczy spotkania ludzi różnych pod wieloma względami. Ważne staje się zatem poszanowanie inności jednostki, przyjęcie założenia, iż mimo braku wzajemnego zrozumienia warto podjąć trud nawiązywania relacji (Sennett 2013, s. 212-213). Sytuację początkującego nauczyciela budującego relacje w nowym dla siebie środowisku odnieść można do sposobu, w jaki Sennett rozumie wzmacnianie relacji. Relacjom służy rozwój rozumiany jako coś więcej niż uczenie się dobrego wykonywania tego, co już nowicjusz umie. To zdobywanie całego pakietu umiejętności stosowanych w różnych sytuacjach. O nabywaniu umiejętności (w tym współpracy) nie świadczy bowiem „poznawanie jednej, właściwej metody, dostrzeżenia środka prowadzącego prosto do celu. Pełen rozwój wymaga jednak nauczenia się podejścia na różne sposoby do tego samego problemu. Bogatszy pakiet technik pozwala na radzenie sobie z trudnymi wyzwaniami” (Sennett 2013, s. 262). Sekwencja rozwijania tak rozumianej umiejętności współpracy oraz korzystania z niej jest długotrwała. Oznacza to, że aby nowicjusz poznał cały wachlarz metod, nauczył się współpracy, potrzeba czasu. Tymczasem opisując cykl kariery zawodowej nauczyciela i związane z nią uczenie się profesji, Michael Huberman (1989) w pierwszej fazie cyklu - nowicjusza - wyróżnia trzy etapy występujące po sobie: wczesny (poszukiwania miejsca), środkowy (zdobywanie nowych umiejętności i wiedzy) i późnego nowicjusza. Nowicjusz uczy się „przetrwania”, a dopiero pod koniec fazy nowicjatu rozwija umiejętność radzenia sobie ze stresem, zaczyna generować własne pomysły, dąży do samouczenia się. Współpracy natomiast będzie się uczył dopiero w kolejnej fazie środka kariery, co powoduje, że działania wspólnotowe mogą wcześniej stanowić dla niego wyzwanie. W tym kontekście celowe jest poszukiwanie odpowiedzi na pytanie, co może pomagać początkującemu nauczycielowi w nawiązywaniu relacji społecznych prowadzących do uczestnictwa w socjokulturowych praktykach wspólnoty? Odnosząc 
się do koncepcji wymagającej współpracy Sennetta, odpowiedzią jest zaufanie, które o ile nie jest związane z zajmowanym stanowiskiem czy relacją nadrzędności-podrzędności, pełni istotną rolę w podtrzymywaniu relacji pozytywnych, sprzyjających społecznemu uczeniu się. Dodać można, że chodzi o zaufanie, które buduje więzi społeczne oparte na poczuciu wspólnoty, a nie na przynależności. Aby obdarzyć kogoś zaufaniem, nowicjuszowi potrzebna jest otwarta komunikacja, dialog, nieformalne więzi społeczne. A te, aby powstały, wymagają bliskości przestrzennej między ludźmi, częstego spotykania się, poczucia, że jest się docenianym. Natomiast w sytuacji, gdy dyskusje odbywają się prywatnie, „po cichu”, nie można mówić o budowaniu więzi, których podstawą są równość i możliwość wyrażania opinii (Sennett 2013, s. 61). Badania wskazują, że nowicjusze ufają instytucjom edukacyjnym, pokładają w szkole duże nadzieje, ich funkcjonowanie w systemie szkolnym podporządkowane jest głębokiej wierze w nieomylność działań szkoły (Curry i in. 2008). Tym samym można przypuszczać, że są otwarci na poznanie społecznego świata miejsca pracy, aktywny udział w konstruowaniu dyskursu na temat podejmowanej przez siebie i innych aktywności.

\section{Początkujący nauczyciel w sytuacji transgresyjnego otwarcia na wspólnotę}

Uczenie się profesji, nadawanie znaczeń działaniom, ich interpretowanie w odniesieniu do doświadczeń własnych - to wszystko ma miejsce we wspólnej dla nauczycieli czasoprzestrzeni. Nauczycieli w niej obecnych łączy podobieństwo doświadczeń, podzielanie wybranych działań, lecz także opowiadanie o własnej aktywności, zwyczaje zachodzące w określonym czasie i przypisane wybranym miejscom. Wiedza, kompetencje i umiejętności, rozwinięte podczas przygotowania do zawodu, nie zawsze przystają do wymagań sytuacji, z którymi spotyka się nauczyciel rozpoczynający pracę. Badania pokazują, że tranzycja nauczyciela z etapu edukacji do praktyki zawodowej jest momentem trudnym dla wielu nauczycieli (Cybal-Michalska 2014, s. 190-200). Formułowane oczekiwania wobec nowicjusza obarczają go odpowiedzialnością, a także określają poziom autonomii, przy czym nie stosuje się rozróżnienia - albo czyni się to w niewielkim zakresie - między wymaganiami stawianymi przed początkującym i doświadczonym nauczycielem. W konsekwencji nowicjusze ponoszą pełną odpowiedzialność za realizację powierzonych zadań od pierwszego dnia pracy. Zjawisko równej odpowiedzialności nauczycieli, bez względu na etap rozwoju zawodowego, jest powszechne na świecie (Deal, Chatman 1989, s. 26). Tymczasem włączanie się w daną społeczność, wspólne konstruowanie sensu podejmowanych działań nie odbywa się z dnia na dzień, ale wymaga stałego uczestniczenia i zaangażowania w jej sprawy (Curry $\mathrm{i}$ in. 2008, s. 661).

Prowadzone od blisko trzech dekad badania nad startem zawodowym nauczycieli wykazały, iż dla pokonywania wyzwań stojących przed nowicjuszem kluczowe znaczenie ma wsparcie (profesjonalne, emocjonalne i społeczne) otrzymywane od 
wspólnoty nauczycieli. Przy czym za czynniki istotne dla pozostania nauczyciela w zawodzie, podnoszące satysfakcję z pracy i wewnętrzną motywacją do nauczania, uznano wielkość sieci oraz postrzeganie przez nowicjusza wsparcia za przydatne. Okazało się, że częstotliwość otrzymywanego wsparcia nie jest istotna (Thomas i in. 2019). W odniesieniu do organizacji pracy nauczycieli przedszkola wynik ten może niepokoić, niejednokrotnie bowiem są to placówki małe, zatrudniające niewielu nauczycieli, a tym samym oferujące ograniczone sieci wsparcia.

Także różnorodność typów wsparcia, którego doświadcza nowicjusz, staje się argumentem przemawiającym za pozostaniem w zawodzie. Richard Ingersoll i Thomas Smith (2004) stwierdzili, że najwyżej oceniane są: praca z mentorem posiadającym taką samą specjalizację jak nowicjusz; wspólne spędzanie czasu (w ramach pracy) z innymi nauczycielami oraz wspólne planowanie pracy. Istotne okazały się także kontakty z innymi początkującymi nauczycielami. Jak widać, wszystkie wysoko oceniane formy wsparcia udzielane nowicjuszowi koncentrują się na relacjach interpersonalnych, działaniach komunikacyjnych, dialogu. Za interpersonalny motyw do opuszczenia zawodu uznano natomiast poczucie wykluczenia społecznego. Niniejszą kwestię odnieść można do ustaleń Kurantowicz (2007, s. 13-20), która opisuje zmieniające się więzi i relacje wewnątrz społeczności, związane z modyfikacją społecznego uczenia się. Dowodzi, że grupy, także zawodowe, coraz częściej odchodzą od kontrolowania przebiegu socjalizacji oczekiwanej czy wymaganej od nowych członków. Jak można przypuszczać, zjawisko odchodzenia wspólnot, w tym edukacyjnych, od tradycyjnych więzi i relacji, a tym samym od proponowania wsparcia, stawia nowicjusza w trudnej sytuacji.

Analiza kluczowych zagadnień związanych z problematyką wsparcia otrzymywanego przez nowo zatrudnionych nauczycieli w ciągu pierwszych lat pracy w zawodzie ujawnia, że w krajach europejskich występuje wysoka różnorodność organizacyjna systemów wsparcia. Celem ich stosowania jest pomoc nowicjuszowi w przezwyciężeniu określonych trudności oraz zmniejszenie prawdopodobieństwa, że początkujący nauczyciele wcześniej odejdą z zawodu. Mimo że nieliczne kraje oferują kompleksowe programy wprowadzające, to wiele $\mathrm{z}$ nich zapewnia indywidualne środki wsparcia. Najczęściej jest to mentoring, w ramach którego doświadczony nauczyciel, wyznaczony przez dyrektora szkoły, podejmuje się opieki nad nowo zatrudnionym nauczycielem (Komisja Europejska/EACEA/Eurydice 2013, s. 37-41). Jednak nawet regularne spotkania $\mathrm{z}$ mentorem nie uczą nowicjusza, jak proaktywnie zaangażować się w działania wspólnoty.

Powstaje pytanie, jaka aktywność jest szczególnie potrzebna nowicjuszowi, aby zaangażować się w sprawy wspólnoty, odnaleźć w niej swoje miejsce, być gotowym na obecną w niej wielość i złożoność możliwości, a równocześnie efektywnie przyczyniać się do transformacji siebie i praktyki edukacyjnej? Odpowiedzią może być propozycja Agnieszki Cybal-Michalskiej (2014, s. 373-383) promowania autonomicznej podmiotowości sprawczej, która sprzyja otwarciu się na nowe możliwości, sytuacje, a nie bezkrytyczne zakotwiczenie w tradycyjnych, homogenicznych 
założeniach i zasadach. Nowicjusz nie powinien czekać na zorganizowanie mu wsparcia, programy adaptacyjne, specjalne warunki pracy. Wybranie poznawczej i behawioralnej proaktywności oznacza, że aktywnie podejmuje działania sprawcze w podejściu do praktyki pedagogicznej, przekraczające formalnie wymagane obowiązki. Pamiętając przy tym, że zakres samoskuteczności w roli związany jest z zaufaniem ze strony innych podmiotów życia społecznego.

\section{Podsumowanie}

Elementy odnoszące się do procesu uczenia się profesji są ze sobą powiązane i obejmują wymiar profesjonalny, społeczny i osobisty. Uczenie się w społeczno-kulturowym świecie miejsca pracy jest konstruowane zarówno społecznie i interaktywnie, jak również jest „wytworem indywidualnego doświadczania siebie w świecie. Jest ono zawsze usytuowane w kulturze, jednakże jest subiektywnym procesem interpretacji jej znaczeń" (Czubak-Koch 2014, s. 202). Ralph Putnam i Hilda Borko (200o), przedstawiając konteksty uczenia się nauczycieli, uważają za oczywiste w tym procesie nabywanie profesjonalnej wiedzy, umiejętności, kompetencji, budowanie tożsamości zawodowej, ale także wiedzę zrekonstruowaną z praktyk społecznych przyjętych w kulturze danej grupy. Jednak za mniej oczywiste, a bezwzględnie niezbędne w uczeniu się uznają aktywne włączanie się nowicjusza w dyskursywną wspólnotę nauczycieli, co może mieć miejsce tylko przez uczestnictwo w działaniach komunikacyjnych danej społeczności. Nawiązując do postawionej we wstępie tezy, iż jedynie partycypacja nowicjusza w działaniach wspólnoty nauczycieli prowadzi do stopniowego stawania się nauczycielem, można powiedzieć, że wymaga ona zarówno aktywności i gotowości nowicjusza, jak i otwarcia się innych nauczycieli na współuczestniczenia nowicjusza w działaniach wspólnotowych. Tym bardziej - na co wskazują wyniki badań nad orientacjami sprawczymi i wspólnotowymi współczesnej młodzieży - że indywidualistyczne tendencje, stanowiące cechę konstytutywną czasów ponowoczesnych, nie stanowią opozycji w stosunku do postrzegania przez młodych ludzi własnych możliwości ukierunkowanych na wspólnotowość (Peret-Drążewska 2014, s. 148).

W tym kontekście można, moim zdaniem, zastanowić się, na ile wspólnoty nauczycieli są gotowe na przyjęcie początkujących nauczycieli, odznaczających się wysokim zaangażowaniem, potrzebą identyfikacji z grupą nauczycieli, chęcią ponoszenia odpowiedzialności, rozumianej jako współuczestniczenie. We wspólnotach nauczycielskich, przy powielaniu znanych od lat procedur postępowania, przy kultywowaniu znanego sposobu organizowania pracy, można oczekiwać, że transgresyjne otwarcie na przekraczanie ustalonych wzorów działania nie będzie powszechną praktyką. Na straży przyjętej kultury stoją bowiem ci, którzy strzegą reguł specyficznie pojmowanej socjalizacji nie tylko nowicjuszy, lecz także osób od dawna obecnych w danej społeczności. Podtrzymywanie przejętych tradycji, niepisanych norm, stylów myślenia, uznawanych za właściwe w danej kulturze, 
dostarcza pragmatycznych wzorów działania i myślenia. Teza ta niepokoi w odniesieniu do sytuacji początkującego nauczyciela, który kwestionując zastany porządek, może być pozbawiony możliwości zaangażowania się w działania wspólnoty. Warto zaakcentować, że kulturę przedszkola można rozważać tylko na zasadzie wzajemności, co oznacza, że budowanie zdolności nauczycieli do doskonalenia własnej praktyki jest możliwe o tyle, o ile przedszkole w kontekście instytucjonalnym systematycznie dba o rozwój swoich nauczycieli (Vujičić 2013). Wyłącznie wspólnoty uczące się budują kulturę krytycznego dialogu, podejmują refleksję nad własnym działaniem, konstruują przestrzeń dla zrozumienia praktyki z innej perspektywy oraz tworzą sieci wsparcia, umożliwiające nowicjuszowi partycypację w dyskursie na temat podejmowanych aktywności.

Wybrane kwestie zostały tylko zasygnalizowane, warto więc moim zdaniem przyjrzeć się wnikliwie jednostkowym, biograficznie uwarunkowanym wzorom postępowania, konstruowanym znaczeniom oraz przestrzeni wspólnotowości obecnej w przedszkolu, temu, co jest i jak jest uzgadniane, dyskutowane, negocjowane, czy dochodzi do wspólnego dookreślania znaczeń, a tym samym do poszerzania społecznego pola uczenia się nowicjusza. Warto podjąć namysł nad tym, jakie praktyki socjokulturowe sprzyjają zrozumieniu, uczeniu się znaczeń obecnych we wspólnocie zawodowej nauczycieli, w którą wstępuje nowicjusz.

\section{Bibliografia}

Barbier J-M. (2016). Leksykon analizy aktywności. Konceptualizacja zwyczajowych pojęć, tłum. Marynowicz-Hetka E., Łódź: Wydawnictwo UŁ.

Cherubini L. (2009). New Teachers' Perceptions of Induction: Insights Into Principled Practices. "The Alberta Journal of Educational Research”, vol. 55, nr 2, s. 185-198.

Curry M., Jaxon K., Russell J.L., Callahan M.A., Bicais, J. (2008). Examining the practice of beginning teachers' micropolitical literacy within professional inquiry communities. „Teaching and Teacher Education”, vol. 24, nr 3, s. 66o-673.

Cybal-Michalska A. (2014). Młodzież akademicka a kariera zawodowa. Kraków: Impuls.

Czubak-Koch M. (2014). Uczenie się w kulturze miejsca pracy. Wrocław: Wydawnictwo Naukowe DSW.

Deal T.E., Chatman R.M. (1989). Learning the ropes alone: Socializing new teachers. "Action in Teacher Education", vol. 11, nr 1, s. 21-29.

Grochowalska M. (2015). Od wiedzy do działania: praca zawodowa $w$ doświadczeniach początkujacych nauczycieli edukacji przedszkolnej. „Przegląd Pedagogiczny", nr 1, s. s. 85-97.

Howes C., James J., Ritchie S. (2003). Pathways to effective teaching. „Early Childhood Research Quarterly", vol. 18, $\mathrm{nr}$ 1, s. 104-120.

Huberman M.A. (1989). The professional life cycle of teachers. „Teachers College Record", vol. 91, nr 1, s. 31-57. 
Ingersoll R., Smith T.M. (2004). Do Teacher Induction and Mentoring Matter? „NAASP Bulletin”, 88, (638), March 2004, s. 28-40, dostępny na: http://repository.upenn.edu/ gse_pubs/134 (otwarty: 15.09.2018).

Kacperczyk A. (2012). Świat społeczny. W: Konecki K.T., Chomczyński P. Słownik socjologii jakościowej. Warszawa: Difin, s. 276-278.

Kelchtermans G. (2017). 'Should I stay or should I go?' Unpacking teacher attrition/retention as an educational issue. „Teachers and Teaching”, vol. 23, nr 8, s. 961-977.

Kędzierska H., Maciejewska M. (2014). Odpowiedzialny nauczyciel - (nie)odpowiedzialna wspólnota - co pomaga, a co przeszkadza w budowaniu nauczycielskich wspólnot praktyków. W: Edukacja jako odpowiedź. Odpowiedzialni nauczyciele $w$ zmieniającym się świecie. Mazurkiewicz G. (red.). Kraków: Wydawnictwo UJ, s. 83-96.

Kołodziej-Durnaś A. (2012). Kultura organizacji - idea i instrumentalizacja. Szczecin: Wydawnictwo Naukowe USz.

Komisja Europejska/EACEA/Eurydice. (2013). Key Data on Teachers and School Leaders in Europe (Kluczowe dane dotyczace nauczycieli i dyrektorów szkót w Europie). Raport Eurydice. Luksemburg: Urząd Publikacji Unii Europejskiej, dostępny na: eurydice.org.pl/wp-content/uploads/2014/10/KDT2013_pl.pdf (otwarty: 15.09.2018).

Kurantowicz E. (2007). O uczacych się społecznościach. Wybrane praktyki edukacyjne ludzi dorosłych. Wrocław: Wydawnictwo Naukowe DSW.

Madalińska-Michalak J. (2016). Wspólnoty praktyków a granice uczenia się nauczycieli w szkole. Rola dyrektora szkoły. W: Szkoła. Wspólnota dążeń? Minczanowska A., Szafraniec-Gajdzica A., Szymański M.J. (red.). Toruń: Wydawnictwo Adam Marszałek, s. 48-61.

Morgan G. (2005). Obrazy organizacji, tłum. Wiankowska-Ładyga Z., Warszawa: Wydawnictwo Naukowe PWN.

Muchacka B., Czaja-Chudyba I. (2018). Bariery i ograniczenia $w$ refleksyjnym rozwoju nauczycieli wczesnej edukacji. „Forum Pedagogiczne”, vol. 8, nr 2, s. 17-32.

Peret-Drążewska P. (2014). Orientacje sprawcze i wspólnotowe współczesnej młodzieży. „Kultura-Społeczeństwo-Edukacja”, vol. 2, nr 6, s. 135-152.

Putnam R.T., Borko H. (2000). What do new views of knowledge and thinking have to say about research on teacher learning? „Educational Researcher”, nr 29, s. 4-15.

Sennett R. (2013). Razem. Rytuały, zalety, i zasady współpracy, tłum. Dzierzgowski J. Warszawa: Muza.

Środa M. (2003). Indywidualizm i jego krytycy. Warszawa: Aletheia.

Thomas L., Tuytens M., Moolenaar N., Devos G., Kelchtermans G., Vanderlinde R. (2019). Teachers' first year in the profession: the power of high quality suport. „Teachers and Teaching”, vol. 25, nr 2, s. 160-188.

Vujičić L. (2013). Researching and Changing Kindergarten Culture and the Quality of Educational Practice, dostępny na: https://www.researchgate.net/ 
publication/265843088_Researching_and_Changing_Kindergarten_Culture_ and_the_Quality_of_Educational_Practice (otwarty: 15.12.2019).

Wojciszke B., Cieślak M. (2014). Orientacja sprawcza i wspólnotowa a wybrane aspekty funkcjonowania zdrowotnego i społecznego. „Psychologia Społeczna”, vol. 93, $\mathrm{nr}$ 30, s. 285-297.

\title{
NOVICE KINDERGARTEN TEACHER IN A PROFESSIONAL COMMUNITY. FROM UNCERTAINTY TO FULL PARTICIPATION IN SOCIOCULTURAL PRACTICES
}

\begin{abstract}
The paper aims at presenting the social dimension of learning the profession by a novice kindergarten teacher, the importance of participation in sociocultural practices of the community in this process. The author develops the hypothesis that only participation of the novice in the activities of the teaching community gradually converts a person into a teacher. First, the author describes the basic term for discussion - "community" perceived in the cultural perspective, with the emphasis on two dimensions: cooperation and trust. Then, the novice's involvement in the community matters and finding one's place there is reviewed. The conclusion includes the discussion about forming a support network to allow the novice to participate in the discourse on the undertaken activities.
\end{abstract}

Keywords: novice teacher; teacher community; teacher socialization; culture of pre-school; pre-school education. 